\author{
MARTA KISIELOWSKA \\ ORCID: 0000-0002-2914-3166 \\ Uniwersytet Jagielloński \\ marta.zapala@uj.edu.pl
}

\title{
Publiczne prawa podmiotowe jednostek samorządu terytorialnego
}

\begin{abstract}
Abstrakt: Tadeusz Bigo w swojej publikacji Zwiąki publiczno-prawne w świetle ustawodawstwa polskiego dokonał analizy pojęcia samorządu terytorialnego, a przede wszystkim relacji państwa względem samorządu. W pracy poruszył niezwykle ważne zagadnienie możliwości przysługiwania jednostkom samorządu terytorialnego publicznych praw podmiotowych. W niniejszym artykule dokonano analizy poglądów T. Bigi na tle obowiązujących uregulowań prawnych oraz stanowiska współczesnej doktryny.
\end{abstract}

Słowa kluczowe: publiczne prawa podmiotowe, podmiotowość publicznoprawna, samodzielność jednostek samorządu terytorialnego, stanowienie prawa miejscowego przez jednostki samorządu terytorialnego.

\section{Wstęp}

Problematyka publicznych praw podmiotowych należy do wciąż żywych $\mathrm{i}$ kontrowersyjnych zagadnień $\mathrm{w}$ doktrynie prawa administracyjnego. Jedną $\mathrm{z}$ budzących wątpliwości kwestii jest odpowiedź na pytanie, kto może być podmiotem publicznych praw podmiotowych. To zagadnienie kluczowe, ponieważ, jak słusznie zauważa Wojciech Jakimowicz, publiczne prawo podmiotowe bez podmiotu jest kategoria pustą ${ }^{1}$ W doktrynie panuje zasadniczo zgoda co do tego, że publiczne prawa podmiotowe przysługują osobom fizycznym i prawnym, brak jest natomiast jednolitości poglądów w odniesieniu do możliwości ich przysługiwania państwu oraz jednostkom samorządu terytorialnego. Kontrowersję tę wyraź-

1 W. Jakimowicz, Publiczne prawa podmiotowe, Kraków 2002, s. 194. 
nie widać w pracy Tadeusza Bigi pod tytułem Zwiąki publiczno-prawne w świetle ustawodawstwa polskiego. Autor, dokonując analizy dzieła Jerzego Panejki², przedstawia swoje niezwykle interesujące rozważania dotyczące hipotetycznego stwierdzenia, że publiczne prawa podmiotowe przysługują również jednostkom samorządu terytorialnego. Zaznaczyć należy, że zagadnienie to jest rzadko podejmowane w doktrynie, a wydaje się łączyć w sobie kluczowe dla dzieła Bigi wątki związane z pojęciem samorządu terytorialnego i jego relacji do państwa.

\section{Definicje publicznych praw podmiotowych}

W teorii prawa publiczne prawa podmiotowe są określane jako złożone sytuacje prawne: bądź to swoisty zespół pochodnej sytuacji prawnej oraz wolności (czy rzadziej: obowiązku), bądź to zespół funkcjonalnie powiązanych ze sobą uprawnień i kompetencji oraz wolności albo obowiązku czynienia $\mathrm{z}$ nich użytku, a więc zespół pochodnych i podstawowych sytuacji prawnych wyznaczanych jakiemuś podmiotowi przez obowiązujące normy prawne ${ }^{3}$. Przy czym zwrot „ma prawo” oznacza, że jakiś podmiot dysponuje „wolnością dwustronną”, ,jest uprawniony”, ma „wolność prawnie chronioną" (jako rodzaj uprawnienia), „kompetencję” i „roszczenie” (jako rodzaj kompetencji) 4 . W przypadku kompetencji przedmiotem prawa ze względu na rozważaną normę kompetencyjną są czynności konwencjonalne podmiotu, w następstwie dokonania których rozważana norma znajduje zastosowanie i aktualizuje obowiązek określonego zachowania podmiotu podległego kompetencji ${ }^{5}$.

W literaturze pojęcie praw podmiotowych jest rozumiane również jako przyznana przez przepisy prawne i wynikająca ze stosunku prawnego sfera możności postępowania osoby fizycznej lub prawnej w określony sposób, umożliwiająca ochronę interesów uprawnionego tylko w granicach określonych przez przepisy prawne. Prawu podmiotowemu odpowiadają obowiązki innych osób, a naruszenie tych obowiązków umożliwia uprawnionemu korzystanie z przymusu aparatu państwowego ${ }^{6}$.

W definicji publicznych praw podmiotowych kluczową rolę odgrywa ich publiczny charakter. Zgodnie ze słownikiem języka polskiego publiczny to dotyczący całego społeczeństwa lub jakiejś zbiorowości; dostępny lub przeznaczony dla wszystkich; związany z jakimś urzędem lub z jakąś instytucją nieprywatną;

2 Autor odwołuje się do publikacji J. Panejki, Geneza samorzadu europejskiego, Paryż 1924.

3 A. Redelbach, S. Wronkowska, Z. Ziembiński, Zarys teorii państwa i prawa, Warszawa 1994, s. 153.

4 Ibidem, s. 150.

5 Ibidem, s. 151.

6 W. Jakimowicz, op. cit., Kraków 2002, s. 164 i cytowana tam literatura. 
odbywający się przy świadkach, w sposób jawny ${ }^{7}$. Słownikowe ujęcie odpowiada postrzeganiu pojęcia „publiczny” przez Jana Zimmermanna, który wskazuje, że może ono być ujmowane od góry lub od dołu. Termin „publiczny”, który rozumiany jest jako zależny od państwa, oznacza, że państwo jest zobowiązane do pieczy, kontroli, regulowania, ustalania, nadzorowania wszystkiego, co mieści się w tym pojęciu ${ }^{8}$. Z kolei ujęcie od dołu oznacza spojrzenie z perspektywy obywatela: należący do ogólu, do wszystkich, czy do większej wspólnoty ${ }^{9}$. Dla określenia publicznych praw podmiotowych znaczenie ma spojrzenie od góry.

Jakimowicz definiuje publiczne prawa podmiotowe jako pochodną i prostą sytuację prawną podmiotu tego prawa, pozwalającą na skuteczne kierowanie żądania ściśle określonego zachowania do objętego tą sytuacją prawną innego zbiorowego podmiotu publicznego prawa podmiotowego.

W doktrynie przyjmuje się, że źródłem publicznych praw podmiotowych są normy prawa przedmiotowego ${ }^{10}$. Ze względu na przyjęte określenia publicznych praw podmiotowych należy założyć, że ich źródłem mogą być normy prawa publicznego, czyli prawa, w którym realizowane są cele, interesy, dobro i zadania publiczne oraz regulowane są organizacja i działalność administracji publicznej ${ }^{11}$. W demokratycznym państwie prawnym źródłem praw podmiotowych mogą być wyłącznie normy zawarte w źródłach prawa powszechnie obowiązującego, przede wszystkim Konstytucji i ustawach.

Analiza przywołanych określeń publicznych praw podmiotowych prowadzi do wniosku, że odwołują się do one do pojęć odgrywających kluczową rolę w prawie administracyjnym, a równocześnie pozbawionych jednoznacznych definicji. Jakimowicz słusznie zwraca uwagę, że ustalenie pojęcia publicznych praw podmiotowych wymaga przyjęcia określonego rozumienia kompetencji i uprawnień, które są używane do jego definiowania ${ }^{12}$. Zaznaczyć należy, że w obrębie prawa administracyjnego pojęcie kompetencji łączy w sobie uprawnienie i obowiązek, a zatem dwa elementy pojawiające się $\mathrm{w}$ definicji publicznych praw podmiotowych. Kompetencja jest to zdolność organu do skonkretyzowania sformułowanego przez prawo obowiązku działania ${ }^{13}$. Pojęcie kompetencji wiąże się ze „Zdolnością”, „możnością”, „upoważnieniem” oraz „uprawnieniem”14. Normy kompetencyjne równocześnie upoważniają (uprawniają) i obligują organ do czynienia użytku z kompetencji w określonym przez normę stanie prawnym. Wydaje

${ }^{7}$ Stownik Języka Polskiego, https://sjp.pwn.pl/szukaj/publiczny.html (dostęp: 1.02.2022).

8 J. Zimmermann, Aksjomaty prawa administracyjnego, Warszawa 2013, s. 50.

9 Ibidem, s. 50.

10 T. Bigo, Związi publiczno-prawne w świetle ustawodawstwa polskiego, Warszawa 1928, s. 143; W. Jakimowicz, op. cit., s. 176.

11 J. Zimmermann, op. cit., s. 51.

12 W. Jakimowicz, op. cit., s. 164.

13 J. Boć, Prawo administracyjne, Wrocław 2007, s. 143.

14 J. Zimmermann, op. cit., s. 163. 
się, że w świetle tych ustaleń przysługiwanie publicznych praw podmiotowych na przykład jednostkom samorządu terytorialnego będzie miało inny charakter niż w wypadku jednostek. Jednostka bowiem sama decyduje, czy będzie korzystać z przysługujących jej praw, tymczasem organy i podmioty wyposażone w kompetencje nie mają swobody decyzyjnej; w przypadku zaistnienia stanu faktycznego W normie prawnej określonego, mają obowiązek tę normę realizować. W przypadku zatem jednostek samorządu terytorialnego istnienie publicznego prawa podmiotowego może się wiązać z obowiązkiem korzystania z niego.

$Z$ przedstawionych definicji publicznych praw podmiotowych nie wynika jednoznacznie, kto może być podmiotem publicznych praw podmiotowych, a w rezultacie nie dają one podstawy do wykluczenia z kategorii podmiotów publicznych praw podmiotowych jednostek samorządu terytorialnego.

W pojęcie prawa podmiotowego wpisane jest istnienie obowiązku określonego działania (lub jego zaniechania) przez jeden podmiot na rzecz innego ${ }^{15}$. W związku z tym w literaturze dokonuje się klasyfikacji publicznych praw podmiotowych na prawa o treści negatywnej, które polegają na roszczeniu o zaniechanie ingerencji w sferę uprzednio przyznanej wolności lub przyznanego stanu prawnego, oraz prawa o treści pozytywnej, które polegają na żądaniu od państwa (organu państwa), aby zapewniło możliwość korzystania z przysługujących świadczeń. W odniesieniu do praw o charakterze negatywnym zwraca się uwagę, że państwo ma normatywny obowiązek nie tylko nieingerowania w sferę praw jednostki, ale też stworzenia skutecznego systemu ochrony i zabezpieczania swobody obywateli przed niedozwoloną ingerencją innych podmiotów ${ }^{16}$.

Według Stanisława Kasznicy publiczne prawa podmiotowe mogą być podzielone na trzy kategorie: 1) prawa wolnościowe, które zapewniają jednostce roszczenie wobec państwa o powstrzymanie się od ingerencji w sferę wolności przysługującej jednostce; 2) prawa polityczne, które gwarantują jednostce udział w procesie wyborczym (w wyborach i referendach) i w ten sposób w sprawowaniu władzy; 3) prawo do pozytywnych świadczeń ${ }^{17}$.

\section{Podmioty publicznych praw podmiotowych}

W literaturze przyjmuje się, że pojęcie publicznego prawa podmiotowego służy określeniu relacji pomiędzy jednostką a państwem. Prawa te stanowią, obok pojęcia interesu faktycznego i prawnego, jeden z elementów triady Bernatzika ukazujących podstawowe relacje podmiotów zewnętrznych i państwa. Publiczne

15 M. Masternak-Kubiak, P. Kuczma, Prawo petycji jako publiczne prawo podmiotowe (aspekt podmiotowy i przedmiotowy), s. 259, http://www.repozytorium.uni.wroc.pl (dostęp: 1.02.2022).

16 W. Jakimowicz, op. cit., s. 224.

17 S. Kasznica, cyt. za: M. Masternak-Kubiak, P. Kuczma, op. cit., s. 262. 
prawa podmiotowe definiowane są jako podstawowe i pochodne sytuacje prawne obywateli, w skład których wchodzi roszczenie prawne ${ }^{18}$. Z istoty pojęcia publicznego prawa podmiotowego wynika zatem, że podstawowym jego podmiotem jest jednostka (obywatel). Wskazuje się, że jednostka, której przysługuje publiczne prawo podmiotowe poprzez dokonanie konwencjonalnej czynności, może wyznaczyć sposób zachowania organom państwa.

W literaturze kontrowersje budzi możliwość przysługiwania publicznych praw państwu, a także jednostkom samorządu terytorialnego. Część autorów zdaje się odrzucać tę możliwość ${ }^{19}$; takie stanowisko prezentował Panejko, wprost wskazując, że jednostkom samorządu terytorialnego nie przysługują publiczne prawa podmiotowe ${ }^{20}$.

Z kolei analiza współcześnie przyjmowanych $\mathrm{w}$ doktrynie definicji prowadzi do wniosku, że publiczne prawa podmiotowe są uznawane za pojęcie opisujące relacje jednostki względem państwa. Adam Błaś i Jan Boć przyjmują, że publiczne prawo podmiotowe oznacza taką sytuację prawną obywateli (jednostki zbiorowej), w obrębie której obywatel, opierając się na chroniących jego interesy prawne normach, może skutecznie żądać czegoś od państwa lub może w sposób niekwestionowany przez prawo coś zdziałać ${ }^{21}$. W ujęciu Małgorzaty Masternak-Kubiak i Pawła Kuczmy publiczne prawo podmiotowe to określony ze względu na normę konstytucyjną stosunek prawny zachodzący między oznaczonym podmiotem danego prawa (adresatem) a podmiotem zobowiązanym do realizacji tego prawa (władzą publiczną). Podmiotem zobowiązanym do działania zgodnego z prawem podmiotowym są władze publiczne, czyli organy państwa i samorządu terytorialnego ${ }^{22}$. Analiza przywołanych definicji prowadzi do wniosku, że w tych ujęciach publiczne prawa podmiotowe są korzyściami, które przysługują określonej jednostce i mogą być przez nią skutecznie realizowane, co zostało poręczone przez porządek prawny. W tych ujęciach publiczne prawa podmiotowe dotyczą wyłącznie relacji administracji publicznej i podmiotów zewnętrznych, a zatem relacji pomiędzy podmiotami znajdującymi się poza państwem. Wydaje się jednak, że zacytowane definicje nie wykluczają uznania, że podmiotem publicznych praw podmiotowych może być jednostka samorządu terytorialnego, zależy to bowiem od pierwotnego ustalenia wzajemnych stosunków państwa i samorządu.

Część autorów wprost opowiada się za uznaniem, że publiczne prawa podmiotowe mogą przysługiwać również innym niż jednostka podmiotom. Jest to konsekwencją wyposażenia ich przez prawodawcę w podmiotowość publicznoprawną osób prawa publicznego, a w konsekwencji przyjęcia, że publiczne prawa

\footnotetext{
18 W. Jakimowicz, op. cit., s. 77.

19 J. Zimmermann, Prawo administracyjne, Warszawa 2020, s. 373.

20 T. Bigo, op. cit., s. 132.

21 J. Boć, op. cit., s. 501.

22 M. Masternak-Kubiak, P. Kuczma, op. cit., s. 263.
} 
podmiotowe mogą przysługiwać jednostkom samorządu terytorialnego, mimo braku ich autonomicznego charakteru ${ }^{23}$.

\section{Stanowisko T. Bigi w kwestii przysługiwania publicznych praw podmiotowych jednostkom samorządu terytorialnego}

Zagadnienie przysługiwania jednostkom samorządu terytorialnego publicznych praw podmiotowych dotyka poruszanego przez Tadeusza Bigę tematu relacji samorządu do państwa. Analiza prezentowanych w doktrynie ujęć publicznych praw podmiotowych, pozwala na stwierdzenie, że przysługują one względem państwa (wyznaczają zachowanie państwa). W rezultacie konieczne jest rozstrzygnięcie, czy w tym aspekcie może dojść do przeciwstawiania samorządu państwu oraz do przyjęcia, że samorząd może być podmiotem publicznych praw podmiotowych.

Bigo był zwolennikiem wielopodmiotowej koncepcji samorządu terytorialnego. Zgodnie z przyjętym przez autora stanowiskiem, pojęcie samorządu zostało wprowadzone po to, aby zaznaczyć, że funkcją zarządzania w sposób samodzielny zajmuje się inny podmiot praw i obowiązków niż państwo ${ }^{24}$. Zdaniem Bigi istota „samorządzenia” wyłącza z zakresu podmiotów samorządzących państwo, gdyż pojęcie to nie powstało dla oznaczenia administracji państwa, lecz przeciwnie: dla odróżnienia i odgraniczenia od administracji państwowej ${ }^{25}$.

Autor przyjmuje, że samorząd terytorialny jest zdecentralizowaną administracją wykonywaną przez samodzielne związki publicznoprawne (samorządowe $)^{26}$. Rozważania Bigi opierają się na następujących tezach: 1) samorząd jest typem decentralizacji, 2) przedmiot samorządowej administracji nie różni się od przedmiotu administracji rządowej, 3) podmiotem administracji samorządowej nie jest państwo, ale odrębne podmioty, odrębne osoby prawne (dopuszczalne jest przeciwstawienie administracji samorządowej i rządowej); 4) jednostki samorządowe jako osoby prawne wyróżniają się tym, że posiadają obowiązki i prawa (publiczne) zapewniające im stanowisko równorzędne z władzami rządowymi, to jest władztwem administracyjnym ${ }^{27}$.

23 W. Jakimowicz, Normatywne uwarunkowania realizowania kompetencji prawodawczych przez organy samorzadu terytorialnego, „Samorząd Terytorialny” 2012, nr 3, s. 166.

24 I. Skrzydło-Niżnik, Model samorzadu terytorialnego w Polsce na tle zagadnień ustrojowego prawa administracyjnego, Kraków 2007, s. 178.

25 T. Bigo, op. cit., s. 105.

${ }^{26}$ Ibidem, s. 154. Autor wskazuje, że pojęcie związku publicznoprawnego i samorządowego są synonimami.

27 Ibidem, s. 140-141. 
W swoich rozważaniach autor przyjmuje, że samorząd stanowi decentralizację administracji publicznej, której samodzielnymi podmiotami są korporacje powołane przez ustawę ${ }^{28}$. Bigo w pracy Zwiąki publiczno-prawne w świetle ustawodawstwa polskiego odwołuje się do publikacji Panejki, a krytyka tego dzieła pozwala na określenie poglądów autora, w szczególności dotyczących przysługiwania jednostkom samorządu terytorialnego publicznych praw podmiotowych. W ocenie Bigi Panejko neguje istnienie praw podmiotowych samorządu wobec państwa ${ }^{29}$. Stwierdzenie to opiera na wypowiedziach Panejki, który przyjmuje, że państwu nie można przeciwstawiać jednostek samorządu terytorialnego, prawa jednostek samorządu terytorialnego bowiem mogą być w każdej chwili odwołane ${ }^{30}$.

Naturalną konsekwencją przyjęcia przez Bigę koncepcji wielopodmiotowości administracji publicznej i samorządu terytorialnego, jest stwierdzenie, że samorząd jako podmiot prawa publicznego dysponuje publicznymi prawami podmiotowymi ${ }^{31}$. Bigo podkreśla, że przysługujące samorządowi publiczne prawa podmiotowe nie są niewzruszalne, obowiązują one tak długo, jak długo w obrocie prawnym obowiązuje norma będąca ich źródłem. Równocześnie z wypowiedzi autora wynika wniosek, że wpływ państwa (władzy ustawodawczej) na treść tych praw nie daje podstaw do przyjęcia, iż są one prawami państwa.

Bigo w swoich rozważaniach odwołuje się do poglądów Waltera Jellinka i Otto Mayera, którzy twierdzili, że jednostki są samodzielnymi podmiotami „własnych" (samodzielnych) praw o pochodnym charakterze (czyli mających źródło w porządku prawnym) ${ }^{32}$. Bigo przyjmuje również, że publiczne prawa podmiotowe czerpią swoje obowiązywanie z normy prawnej, a zatem ich źródłem jest prawo przedmiotowe ${ }^{33}$. W ocenie autora bycie podmiotem praw publicznych oznacza możliwość określenia zachowania państwa oraz jego organów. Wpisuje się to we współczesne ujęcie publicznych praw podmiotowych, które pozwalają determinować treść zachowania organów administracji publicznej. Bigo podkreśla, że osobowość (podmiotowość) prawna oznacza zdolność do stawania się podmiotem praw i obowiązków, a zatem także publicznych praw podmiotowych ${ }^{34}$. W jego ocenie struktura praw samorządowych odpowiada ogólnemu schematowi prawa podmiotowego. W ramach niego autor wyróżnia: prawa, którym odpowiadają pozytywne obowiązki innych podmiotów, oraz prawa, którym odpowiednikiem są obowiązki państwa zaniechania pewnych aktów, a te, w ocenie Bigi, nie różnią się od innych publicznych praw podmiotowych przysługujących jednostkom wobec państwa ${ }^{35}$. Autor wskazuje, że prawom podmiotowym gminy odpowiada obowiązek państwa

28 Ibidem, s. 152.

29 Ibidem, s. 130.

30 Ibidem.

31 I. Skrzydło-Niżnik, op. cit., s. 181.

32 T. Bigo, op. cit., s. 131 i cytowana tam literatura.

33 Ibidem, s. 132.

34 Ibidem, s. 141.

35 Ibidem, s. 142. 
polegający na nienaruszalności granic zakresu działania gminy ${ }^{36}$. W rezultacie wydaje się, że kategorię publicznych praw podmiotowych przysługujących jednostkom samorząa terytorialnego ogranicza do wyróżnianej w doktrynie kategorii negatywnych publicznych praw podmiotowych.

Iwona Niżnik-Dobosz, dokonując analizy poglądów Bigi, zwraca uwagę na fakt, że uzasadnienie istnienia publicznych praw podmiotowych samorządu terytorialnego w stosunku do państwa opiera się na instytucji norm sankcjonowanych i norm sankcjonujących. Różnica pomiędzy kompetencjami gminy a kompetencjami organów administracji publicznej (działających w imieniu państwa) polega na tym, że gmina wykonuje swoje prawa w imieniu własnym. W ocenie autorki różnica wyraża się w sankcjach związanych z wykonywaniem kompetencji ${ }^{37}$. Jak bowiem przyjmował Bigo, inne są środki obrony kompetencji organu pozostającego w zależności hierarchicznej, inne zaś organu samorządowego. Wojewoda nie może zaskarżyć decyzji ministra do Najwyższego Trybunału Administracyjnego (dalej: NTA), ponieważ jego kompetencja nie jest prawem podmiotowym, natomiast gmina może zaskarżyć decyzję wojewody do NTA, ponieważ jest podmiotem prawnym ${ }^{38}$. Podkreślić należy aktualność tej tezy: jednostkom samorządu terytorialnego przysługuje prawo skargi do sądu administracyjnego jako środek ochrony ich samodzielności.

\section{Publiczne prawa podmiotowe jednostek samorządu terytorialnego a regulacja konstytucyjna}

Dokonanie oceny, czy jednostkom samorządu terytorialnego przysługują publiczne prawa podmiotowe, wymaga odwołania się do postanowień obowiązującej Konstytucji. Zgodnie z art. 16 Konstytucji RP samorząd uczestniczy w sprawowaniu władzy publicznej, a przysługującą mu w ramach ustaw istotną część zadań publicznych wykonuje w imieniu własnym i na własną odpowiedzialność. Przepis ten wyraża zasadę samodzielności samorządu terytorialnego. W doktrynie wskazuje się, że zwrot „w imieniu własnym i na własną odpowiedzialność” ma na celu podkreślenie zasady decentralizacji i samodzielności samorządu terytorialnego oraz rozgraniczenie zakresu władzy publicznej administracji samorządowej i rządowej. Sformułowanie to oznacza również odpowiedzialność prawną i polityczną jednostek samorządu terytorialnego, a także ich organów, za sposób sprawowania władzy publicznej ${ }^{39}$. Równocześnie Trybunał Konstytucyjny w swoich orzeczeniach

36 Ibidem, s. 146.

37 I. Skrzydło-Niżnik, op. cit., s. 183.

38 T. Bigo, Prawo administracyjne. Część ogólna (stenogram wykładów uniwersyteckich, wyd. Juliusz Rodkowski), [Lwów?] 1932, cyt. za: I. Skrzydło-Niżnik, op. cit., s. 183.

39 P. Tuleja, Konstytucja Rzeczpospolitej Polskiej. Komentarz, Warszawa 2019, LEX/el. 
podkreśla, że jednostki samorządu są integralnym elementem struktury władzy publicznej w państwie, a pozostający w ich dyspozycji zakres władztwa publicznego nie jest ich własną „władzą”, lecz przejawem zdecentralizowanej władzy państwowej, władzy tego samego, jednego państwa polskiego" 40 . Istnienie samorządu nie jest bowiem przejawem autonomii, lecz decentralizacji władzy publicznej.

Artykuł 163 Konstytucji stanowi, że samorząd terytorialny wykonuje zadania publiczne niezastrzeżone przez Konstytucję i ustawy dla organów innych władz publicznych. W literaturze podnosi się, że zawiera on formułę domniemania właściwości na rzecz samorządu terytorialnego ${ }^{41}$. Oznacza to, że w sferze zadań samorządu państwo ma obowiązek powstrzymać się od działania. Możliwe jest oczywiście powierzenie zadań w drodze ustawy innym władzom publicznym, jednakże, jak się wskazuje, musi to być dokonane zgodnie z zasadą subsydiarności ${ }^{42}$.

Zgodnie z art. 165 ust. 1 Konstytucji jednostki samorządu terytorialnego mają osobowość prawną, przysługuje im prawo własności i inne prawa majątkowe, a ich samodzielność podlega ochronie sądowej. Samorząd jest podmiotem praw i obowiązków, przysługują mu też mechanizmy służące obronie przyznanej przez prawo samodzielności, a ponadto prawa podmiotowe (między innymi własności). Z zacytowanych postanowień Konstytucji wynika, że samorząd terytorialny został wyposażony przez prawodawcę $\mathrm{w}$ podmiotowość prawną $\mathrm{w}$ sferze prawa publicznego, a ponadto zostały mu przyznane mechanizmy służące obronie przysługujących mu praw.

W doktrynie wyróżnia się kilka teorii samorządu terytorialnego: naturalistyczną, naturalistyczno-państwową, państwową, socjologiczną oraz polityczną ${ }^{43}$. W ogólnym ujęciu samorząd stanowi formę korporacji, której państwo przekazało część swojej funkcji administracyjnej, wyposażając go w osobowość prawną w obrębie prawa publicznego ${ }^{44}$ (oczywiście też prywatnego). Analiza postanowień Konstytucji prowadzi do wniosku, że została w niej przyjęta państwowa teoria samorządu lokalnego, zgodnie z którą samorząd powstaje przez przekazanie mieszkańcom i ich wspólnotom części funkcji państwa polegającej na sprawowaniu administracji publicznej ${ }^{45}$.

Wojciech Jakimowicz wskazuje, że podmiotowość publicznoprawna jednostek samorządu terytorialnego powinna być uzasadniona państwową teorią samorządu ${ }^{46}$. Istota samorządu polega na wykonywaniu praw zwierzchnich, odstąpionych przez państwo korporacjom samorządowym jako ich własne prawo.

40 Por. wyrok TK z dnia 26 maja 2015 roku, sygn. Kp 2/13, OTK ZU 5A/2015, poz. 65.

41 M. Masternak-Kubiak, [w:] Konstytucja Rzeczypospolitej Polskiej. Komentarz, red. M. Haczkowska, Warszawa 2014.

42 Ibidem.

43 I. Skrzydło-Niżnik, op. cit., s. 167 n.

44 J. Zimmermann, Prawo..., s. 180.

45 Ibidem.

46 W. Jakimowicz, Publiczne..., s. 206. 
W tak rozumianym samorządzie upatruje się skrystalizowania publicznego prawa podmiotowego określanego jako możność rozporządzania władzą publiczną, a uznanie osobowości prawnej jednostek samorządu terytorialnego łączy się z ich prawem do samodzielnego sprawowania części administracji publicznej ${ }^{47}$.

Prawa te przysługują wszystkim wspólnotom samorządowym: gminnym, lokalnym, regionalnym ${ }^{48}$. Polegają one przede wszystkim na możności rozporządzania władzą publiczną przez jednostki samorządu terytorialnego w sposób i na zasadach określonych przez prawo przedmiotowe. Publiczne prawa podmiotowe jednostek samorządu terytorialnego odpowiadają prawom, z których korzystają osoby fizyczne, nie mogą się one jednak mieścić w zakresie, w jakim jednostki te działają w imieniu państwa. Każda jednostka ma prawo żądania nieingerowania w sferę przyznanej jej przepisami prawa samodzielności. Jednostki mają zagwarantowane prawo podmiotowe do skargi do sądu administracyjnego, a także do żądania części dochodów publicznych na realizację zadań samorządowych ${ }^{49}$.

Wskazać należy, że państwo ma zabezpieczać pozycję samorządu, przyznając mu roszczenie o zachowanie przyznanego zakresu zadań i samodzielności. Wpisuje się to zatem w prezentowane przez Bigę poglądy dotyczące charakteru publicznych praw podmiotowych samorządu terytorialnego, polegających na możliwości żądania nieingerowania przez państwo w sferę przyznanej uprzednio wolności.

\section{Marian Zimmermann o publicznych prawach podmiotowych samorządu terytorialnego}

Rozważając zagadnienie publicznych praw podmiotowych samorządu terytorialnego, warto przywołać twierdzenie sformułowane przez Mariana Zimmermanna w publikacji Terenowe przepisy prawne na ziemiach polskich ${ }^{50}$. Autor ten, prowadząc rozważania nad prawem miejscowym, odwołał się do prawa stanowionego przez organy niemieckiego samorządu terytorialnego i wskazał, że wydawane przezeń przepisy były przejawem autonomii stanowiącej „publiczne prawo podmiotowe związku samorządowego" ${ }^{51}$. W przysługującym związkom samorządowym władztwie korporacyjnym mieściło się wydawanie przepisów terenowych $^{52}$, które ograniczone było podmiotowo (tylko do członków danej wspól-

47 Ibidem, s. 207.

48 Ibidem, s. 206.

49 Por. art. 165 ust. 2, art. 167 ust. 1 Konstytucji RP. Gmina ma również prawo podmiotowe do określania własnych podatków, por. art. 168 Konstytucji. Zob. też ibidem, s. 201.

50 M. Zimmermann, Terenowe przepisy prawne na ziemiach polskich, Poznań 1963.

51 Ibidem, s. 11.

52 Ibidem, s. 16. 
noty) oraz przedmiotowo (tylko do własnych spraw samorządu). Równocześnie autor zastrzegał, że prawo to może zostać rozszerzone przez ustawodawcę.

Jak wskazano, analiza postanowień Konstytucji i charakteru samorządu terytorialnego wyklucza przyjęcie, że stanowienie prawa miejscowego może przejawem autonomii jednostek samorządu terytorialnego, ponieważ istnienie samorządu terytorialnego wyrazem decentralizacji władzy publicznej, a nie ich autonomii. Zaznaczyć jednak należy, że zgodnie ze słownikiem języka polskiego autonomia to „prawo jakiejś zbiorowości do rozstrzygania swoich spraw wewnętrznych”, „samodzielność i niezależności w decydowaniu o sobie" ${ }^{53}$. W takim ujęciu autonomia odpowiada raczej pojęciu „samodzielności” samorządu terytorialnego, a nie całkowitej odrębności i niezależności od państwa. Przyjęcie zatem słownikowego znaczenia terminu autonomii (synonimu samodzielności) pozwala stwierdzić, że stanowienie prawa miejscowego przez jednostki samorządu terytorialnego jest jednym z elementów ich samodzielności, a zatem w takim ujęciu stwierdzenia Zimmermanna nie pozostaje w opozycji do aktualnych uregulowań konstytucyjnych.

W świetle zaprezentowanych ustaleń zasadnym wydaje się przyjęcie, że jednostkom samorządu terytorialnego przysługują prawa podmiotowe względem państwa. Te w szczególności polegają na nieingerowaniu w sferę samodzielności samorządu, a także stworzeniu systemu ochrony i zabezpieczenia tych praw przed niedozwoloną ingerencją innych podmiotów. Przy tak określonych założeniach można stwierdzić, że obowiązująca Konstytucja daje podstawy do przyjęcia, iż prawo stanowienia prawa o charakterze powszechnie obowiązującym przez organy jednostek samorządu terytorialnego jest publicznym prawem podmiotowym. Zgodnie bowiem z art. 94 Konstytucji RP organy samorządu oraz terenowe organy administracji rządowej, na podstawie i w granicach upoważnień zawartych w ustawie, ustanawiają akty prawa miejscowego obowiązujące na obszarze działania tych organów. Konstytucja określa zatem prawo jednostek samorządu terytorialnego (oraz terenowych organów administracji rządowej) do stanowienia prawa miejscowego, choć oczywiście każdorazowo jego realizacja przez konkretny organ samorządu terytorialnego wymaga istnienia ustawowej podstawy prawnej.

Wskazać należy, że art. 169 ust. 4 Konstytucji RP stanowi, że ustrój wewnętrzny jednostek samorządu terytorialnego określają w granicach ustaw ich organy stanowiące. Niewątpliwie zatem Konstytucja zawiera normatywną podstawę stanowienia przepisów o charakterze ustrojowym. Jak już podniesiono, samodzielność organizacyjno-ustrojowa jest istotą samorządu jako odrębnego podmiotu prawa publicznego w państwie ${ }^{54}$. Z kolei w ocenie Marka Szewczyka stanowienie przez samorząd terytorialny aktów prawa miejscowego wymaga co do zasady „upoważnienia kazuistycznego”, a zatem upoważnienia wyraźnego i szczegółowego zawartego w ustawie. Tymczasem akty określające ustrój jed-

53 Stownik Języka Polskiego, https://sjp.pwn.pl/szukaj/autonomia.html (dostęp: 1.02.2022).

54 Por. P. Tuleja, op. cit. 
nostek samorządu terytorialnego mogą być kreowane w granicach określonych przez ustawy, a podstawą normatywną do ich stanowienia może być sama norma wyrażona w Konstytucji ${ }^{55}$. W tym zatem kontekście już sama Konstytucja jest źródłem prawa samorządu terytorialnego do stanowienia prawa miejscowego regulującego ustrój.

Artykuł 168 Konstytucji z kolei stanowi, że jednostki samorządu terytorialnego mają prawo ustalania wysokości podatków i opłat lokalnych w zakresie określonym w ustawie. Prawo to jest realizowane przez stanowienie aktów prawa miejscowego, jednakże kompetencja w tym zakresie jest reglamentowana przez ustawodawcę, wskazującego rodzaje podatków i opłat zaliczonych do kategorii podatków i opłat lokalnych, co do których dopuszczalne jest określanie ich wysokości przez jednostki samorządu terytorialnego ${ }^{56}$. W rezultacie nie jest możliwe uznanie, że art. 168 Konstytucji może być samodzielną podstawą stanowienia prawa miejscowego przez organy samorządu.

Analiza prawa do stanowienia przepisów prawa miejscowego przez organy samorządu terytorialnego wymaga zatem sięgnięcia do uregulowań zarówno konstytucyjnych, jak i ustawowych, które precyzują i rozwijają założenia określone w Konstytucji. Trzeba jednak zaznaczyć, że w prawie administracyjnym szeroko akceptowana jest derywacyjna koncepcja wykładni, zgodnie z którą norma może być konstruowana w oparciu o przepisy mogące się znajdować w różnych jednostkach redakcyjnych, a nawet w aktach prawnych różnego rzędu. Nie ma zatem przeszkód, aby dekodować normę określającą publiczne prawo podmiotowe w oparciu o przepisy ustawowe i konstytucyjne. Co więcej, w świetle ustaleń Bigi możliwość zmiany prawa określającego kompetencje samorządu do stanowienia prawa miejscowego nie daje podstaw do przyjęcia, że są to prawa państwa. Fakt zatem, uzależnienie treści prawa stanowienia przepisów miejscowych od prawodawcy nie wyłącza możliwości uznania ich za publiczne prawa podmiotowe.

Jak wskazano, publiczne prawa podmiotowe jednostek samorządu terytorialnego oznaczają możliwość żądania nieingerowania przez państwo $\mathrm{w}$ sferę przyznanych uprzednio praw. W związku $\mathrm{z}$ tym, w zakresie przyznanym przez Konstytucję oraz w ustawy, jednostki samorządu terytorialnego mają prawo żądania powstrzymywania się od ingerencji w sferę przekazaną prawodawcy lokalnego. Tezę tę w odniesieniu do prawa stanowienia przepisów miejscowych zdają się potwierdzać przyjęte uregulowania dotyczące nadzoru, w szczególności nad realizacją kompetencji prawotwórczych ${ }^{57}$. Konstytucyjnie określonym

55 M. Szewczyk, Quasi-autonomia jednostek samorzadu terytorialnego w zakresie określania ustroju wewnętrznego - w świetle postanowień Konstytucji RP, [w:] Konstytucyjne umocowanie samorząu terytorialnego, red. M. Stec, K. Małysa-Sulińska, Warszawa 2018, s. 246.

56 Wyrok TK z dnia 9 kwietnia 2002 roku, sygn. K. 21/2001, LexisNexis nr 357953, OTK-A 2002, nr 2, poz. 17.

57 M. Kisielowska, Pojęcie terenowych przepisów prawnych i ich klasyfikacja $w$ poglądach Profesora Mariana Zimmermanna a dzisiejsze koncepcje prawa miejscowego, [w:] Myśl Mariana 
kryterium nadzoru jest legalność, a zgodnie z postanowieniami ustaw ustrojowych, organy nadzoru mogą wkraczać w działalność jednostek samorządu terytorialnego tylko $\mathrm{w}$ przypadkach określonych ustawami ${ }^{58}$. Wyraźnie zatem ustawodawca uregulował kwestie nadzoru tak, aby chronić samodzielność jednostek samorządu terytorialnego oraz uniemożliwić organom nadzoru wkraczanie w nią w innych sytuacjach niż naruszenie prawa przez organy samorządowe. Co więcej, istota praw podmiotowych polega również na tym, że państwo ma zagwarantować możliwość korzystania z nich przez uprawniony podmiot oraz stworzenie warunków do tego korzystania, co w szczególności przejawia się zakazem ingerencji organów nadzoru w działalność prawodawczą poza sytuacjami określonymi przez prawo i dokonanie jej wyłącznie w oparciu o kryterium legalności. Konstytucja daje ponadto jednostkom samorządu terytorialnego możliwość obrony przysługujących praw przed sądem administracyjnym, które jest w szczególności realizowane przez skargę na akt nadzoru. W rezultacie, wydaje się zasadne uznanie za M. Zimmermannem, że prawo do stanowienia prawa miejscowego jest publicznym prawem podmiotowym jednostek samorządu terytorialnego ${ }^{59}$.

\section{Podsumowanie}

Bigo prowadził swoje rozważania na temat związków publicznoprawnych, ich istoty, a także pojęcia samorządu terytorialnego oraz jego relacji do państwa prawie sto lat temu. Lektura tez i twierdzeń autora prowadzi do kilku wniosków. Rozważania podjęte przez Bigę ukazują, że problem przysługiwania publicznych praw podmiotowych jednostkom samorządu terytorialnego nie musi być wyłącznie postrzegany przez pryzmat samego pojęcia publicznych praw podmiotowych. Kluczowe znaczenie na gruncie tego zagadnienia odgrywa samo rozumienie pojęcia samorządu. W przypadku bowiem uznania, że pomiędzy samorządem i państwem nie ma jednolitości, że można te pojęcia sobie przeciwstawiać, otwarta jest droga do uznania, że publiczne prawa podmiotowe mogą przysługiwać samorządowi względem państwa. Jest to być może oczywisty wniosek, jednakże w mojej ocenie pozwala on ukazać kilka niezwykle istotnych zagadnień.

Przede wszystkim analiza dzieła Bigi potwierdza, jak bardzo potrzebne jest dbanie o jedność prawa administracyjnego. Mimo że prawo administracyjne jest niezwykle rozległe, nieskodyfikowane, to jednak więzy pomiędzy jego normami

\footnotetext{
Zimmermanna a współczesne prawo administracyjne, red. L. Staniszewska, M. Szewczyk, J. Zimmermann, Warszawa 2020, s. 61.

58 Por. art. 87 u.s.g., art. 76 ust. 2 u.s.p., art. 78 ust. 2 u.s.w.

59 Trzeba zwrócić uwagę, że w przypadku aktów prawa miejscowego stanowionego przez organy administracji rządowej, szeroko zostały określone kompetencje do ich zmiany bądź uchylenia przez Prezesa RM. Por. art. 61 ustawy o wojewodzie i administracji rządowej.
} 
są wystarczająco ścisłe, aby mówić o jedności tej gałęzi prawa ${ }^{60}$. Wyraźnie można to dostrzec w ujęciu dzieła Bigi. Ustalenia dotyczące ustrojowego prawa administracyjnego wpływają bezpośrednio na zagadnienie publicznych praw podmiotowych, które zaliczamy tradycyjnie do materialnego prawa administracyjnego. Jest to istotne nie tylko dla przedstawicieli doktryny, ale też dla prawodawcy, który czasami zdaje się zapominać, że uchwalane przez niego ustawy nie funkcjonują w próżni, lecz stanowią element rozbudowanego prawa administracyjnego. W rezultacie wpływają na pozostałe uregulowania tej gałęzi prawa, mogąc prowadzić do zaburzeń i sprzeczności w jej obrębie. Jest to również wskazówka dla doktryny. Prowadząc rozważania, ustalenia terminologiczne, nie możemy się ograniczać do wycinka analizowanego prawa administracyjnego, konieczne jest całościowe spojrzenie nie tylko na tę gałąź, ale również system prawa. Jedność prawa administracyjnego w ocenie J. Zimmermanna może być uznana za aksjomat, czyli cechę odróżniającą prawo administracyjne od innych gałęzi prawa ${ }^{61}$.

Analiza dzieła Bigi prowadzi również do stwierdzenia, że warto sięgać po tak zwane „klasyczne tematy” prawa administracyjnego, nie ma bowiem, jak się wydaje, sfery, w której powiedziano już wszystko, postanowiono „kropkę nad i”. Prawo administracyjne w swej dynamiczności i zmienności wymaga również ciągłego redefiniowania, weryfikowania, uaktualniania kluczowych pojęć. Niewątpliwie do tematów, do których warto wracać, zaliczyć należy publiczne prawa podmiotowe, a sięgnięcie do klasycznych pozycji doktryny prawa administracyjnego, takich jak dzieło Bigi, może stanowić impuls do poszukiwania nowych płaszczyzn badawczych.

\section{Bibliografia}

Bigo T., Prawo administracyjne. Częssć ogólna (stenogram wykladów uniwersyteckich), [Lwów 1932?].

Bigo T., Zwiąki publiczno-prawne w świetle ustawodawstwa polskiego, Warszawa 1928.

Boć J., Prawo administracyjne, Wrocław 2007.

Jakimowicz W., Normatywne uwarunkowania realizowania kompetencji prawodawczych przez organy samorzadu terytorialnego, „Samorząd Terytorialny” 2012, $\mathrm{nr} 3$.

Jakimowicz W., Publiczne prawa podmiotowe, Kraków 2002.

Konstytucja Rzeczypospolitej Polskiej. Komentarz, red. M. Haczkowska, Warszawa 2014.

Kisielowska M., Pojęcie terenowych przepisów prawnych i ich klasyfikacja w pogladach Profesora Mariana Zimmermanna a dzisiejsze koncepcje prawa miejscowego, [w:] Myśl Mariana Zimmermanna a wspótczesne prawo administracyjne, red. L. Staniszewska, M. Szewczyk, J. Zimmermann, Warszawa 2020.

Masternak-Kubiak M., Kuczma P., Prawo petycji jako publiczne prawo podmiotowe (aspekt podmiotowy i przedmiotowy), http://www.repozytorium.uni.wroc.pl.

60 J. Zimmermann, Aksjomaty..., s. 46.

61 Ibidem, s. 8. 
Redelbach A., Wronkowska S., Ziembiński Z., Zarys teorii państwa i prawa, Warszawa 1994.

Szewczyk M., Quasi-autonomia jednostek samorządu terytorialnego w zakresie określania ustroju wewnętrznego - w świetle postanowień Konstytucji RP, [w:] Konstytucyjne umocowanie samorzadu terytorialnego, red. M. Stec, K. Małysa-Sulińska, Warszawa 2018.

Tuleja P., Konstytucja Rzeczypospolitej Polskiej. Komentarz, Warszawa 2019, LEX/el.

Skrzydło- Niżnik I., Model samorząu terytorialnego w Polsce na tle zagadnień ustrojowego prawa administracyjnego, Kraków 2007.

Zimmermann J., Aksjomaty prawa administracyjnego, Warszawa 2013.

Zimmermann J., Prawo administracyjne, Warszawa 2020.

Zimmermann M., Terenowe przepisy prawne na ziemiach polskich, Poznań 1963.

\title{
Public Subjective Rights of Territorial Self-Government Entities
}

\author{
Summary
}

In his publication Public Law Associations in the Light of Polish Legislation, Tadeusz Bigo carries out an analysis of the territorial self-government concept and, most importantly, the relation of the state to the local government. The author raises an immensely important issue regarding the possibility of entitlement to public subjective rights by the territorial self-government entities. The following article examines the views of Tadeusz Bigo against the background of applicable legal provisions and the contemporary doctrine.

Keywords: public subjective rights, public law subjectivity, independence of territorial self-government entities, enacting local law by territorial self-government entities. 